\title{
The development and evolution of landform based on neotectonic movement: The Sancha river catchment in the southwestern China
}

\author{
Lingmin Zhong ${ }^{1}, \mathrm{Mo} \mathrm{Xu}^{1, *}$, Yanna YAng ${ }^{1}$ and XingBing WAng ${ }^{2}$ \\ ${ }^{1}$ State Key Laboratory of Geohazard Prevention and Geoenvironment Protection, Chengdu University of \\ Technology, Sichuan, Chengdu 610 059, China. \\ ${ }^{2}$ Guizhou Normal University, Guiyang 550 001, China. \\ *Corresponding author. e-mail: 875924113@qq.com
}

MS received 24 March 2017; revised 28 June 2017; accepted 29 June 2017; published online 14 February 2018

Neotectonics has changed the coupled process of endogenic and exogenic geological dynamics, which mold the modern landform. Geomorphologic analysis is essential for identifying and understanding the tectonic activity and indicates the responsive mechanism of the landform to tectonic activity. At first, this research reconstructed the twisted Shanpen period planation surface, computed the valley floor width-to-height ratio of Sancha river and extracted the cross sections marking the river terraces to analyze the characteristics of the neotectonics. And then, the relation between neotectonic movement and landform development was analyzed by dividing the landform types. At last, the spatial variation of landform evolution was analyzed by extracting the Hypsometric Integral of sub-catchments. The Sancha river catchment's neotectonic movement presents the tilt-lift of earth's crust from NW to SE, which is characterized by the posthumous activity of Yanshan tectonic deformation. The spatial distribution of river terraces indicates that Sancha river catchment has experienced at least four intermittent uplifts and the fault blocks at both the sides of Liuzhi-Zhijin basement fault have differentially uplifted since the late Pleistocene. As the resurgence of Liuzhi-Zhijin basement fault, the Sancha river catchment was broken into two relative independent landform units. The spatial variations of the landform types near the Sancha river and the sub-catchments' landform evolution are characterized by periodic replacement. The styles of geological structure have controlled the development of landform far away from the Sancha River and influenced the landform evolution. The posthumous activities of the secondary structure have resulted in the spatial variation of sub-catchments' landform evolution, which presents periodic replacement with local exceptions. The present study suggests that spatial variations of the development and evolution of modern landform of Sancha River catchment owe their genesis to the interplay between the hydrodynamic force and tectonic activity in the neotectonic period. Likewise, the application of geomorphic indicators also provides a new way to assess the regional crustal stability.

Keywords. Sancha river catchment; geomorphic indicators; neotectonics; modern landform.

\section{Introduction}

The landform development and evolution are the products of the coupled process of endogenic and exogenic geological dynamics (Finnegan et al. 2008). Since Neogene period, tectonic movement has changed the coupled process and became the 
key factor to control the development and evolution of modern landform (Kothyari and Rastogi 2013; Jiang et al. 2016; Rana et al. 2016). With the recent development of geodetic tools and ' $3 \mathrm{~S}$ ' techniques, it is possible to facilitate the acquisition of accurate rates in tectonic activity and quantify the development and evolution of landform (Asode et al. 2016; Gomez et al. 2016). And the research of the neotectonic movement has been unprecedentedly developed. However, the definition of neotectonic movement of China, especially its beginning, showed considerable differences, which varied from 40 to 0.73 Ma BP (Liu et al. 1994; Gong 2004; Gao 2008; Xu et al. 2012; Liu et al. 2014). Nowa-days, most scholars have agreed that the start time of neotectonic movement is Pliocene (5.3 Ma BP) (Gong 2004; Balen et al. 2005; Liu et al. 2014). Neotectonic movement led to the deformations in earth's crust and controlled the development of modern geomorphology and has also affected the natural social phenomena such as geological hazards, land use planning and management (Cloetingh and Cornu 2005). The theory and method of neotectonic research have been multi-disciplinary involving integration of data from the aspects of structural geology, geomorphology, stratigraphy and geodesy.

The drainage pattern in tectonically active regions is very sensitive to crustal movement such as folding and faulting (Gürbüz et al. 2015). The crust deformation can change the way and the strength of water-flow movement, which makes the development and evolution of landform have obvious spatial variability. The geomorphic indicators serve as indicators for the tectonic activity (Kothyari and Rastogi 2013; Benvenuti et al. 2016; Ramkumar et al. 2016). A correct identification of the neotectonic movements is significant in understanding the development and evolution of modern landforms. Guizhou plateau is located in the southeast edge of Tibetan plateau, and its neotectonic movement is the reflection of the uplift and lateral growth of the Tibetan Plateau and characterized by the tilt-lift from $\mathrm{W}$ to $\mathrm{E}$ (Lin 1985, 1993). However, the crustal deformation in the neotectonic period is very complicated due to the unique fault-block basement, and the results of relevant research are rare. Therefore, it is necessary to analyze the characteristics of the tectonic activity of Guizhou plateau in the neotectonic period for researching the modern geomorphology. Likewise, the response process of modern geomorphology to tectonic activity should be revealed deeply under the background of neotectonics.

The Sancha river catchment is located in the northwest edge of the Guizhou and is most affected by uplift of Tibetan Plateau in the Guizhou Plateau. Therefore, it is a good research object to study the interactions between the neotectonics and the development and evolution of modern landform. Therefore, the present study attempts to understand the concrete form of neotectonic movement, and how it has controlled the development and evolution of modern landform.

\section{Geologic and tectonic setting}

The Sancha river catchment is situated in the northwest of the Upper Yangzi Platform fold belt. The western side is adjacent to the Kangdian Axis, and the northern side is connected with the south of the Sichuan platform depression (figure 1). As the most important headwaters in the Wujiang that flows into the Yangtze River, it covers $8.8 \%$ of Wujiang catchment with a surface area of $7624 \mathrm{~km}^{2}$. The river is $325.6 \mathrm{~km}$ in length and flows from an altitude of over 2500-900 m. Its catchment is dominated by the NE and NW trend fluvial systems.

The study area is characterized by thin-skinned tectonics, and the basement is divided into several fault blocks by basement faults (figure 2; Yue et al. 1994; Feng et al. 2007). The NW basement fault, which is called Weining-Ziyun basement fault was formed in Caledonian Movement at the end-Silurian. It transformed into the NW fault-fold belt due to the strong compression of Indian Ocean plate during the Yanshan movement period. From the Himalaya movement to date, it has resurged because of further compression of Indian Ocean plate (Mao et al. 1997; Wang et al. 2006). Liuzhi-Zhijin basement fault, which derived from Guiyang-Puding basement fault, was formed during the mid-episode of Yanshan movement period (Yue et al. 1994; Dou et al. 2012). It is characterized by multistage thrust activity. Upper Cretaceous was cutoff and folded, which revealed the resurgence of Liuzhi-Zhijin basement fault since the Cenozoic (Lin 1993). The tectonic stress mainly has concentrated on the boundary of these basement fault blocks. The basement, which was comprised of several fault blocks, is an important factor influencing the latter deformation of the cover. The cover 


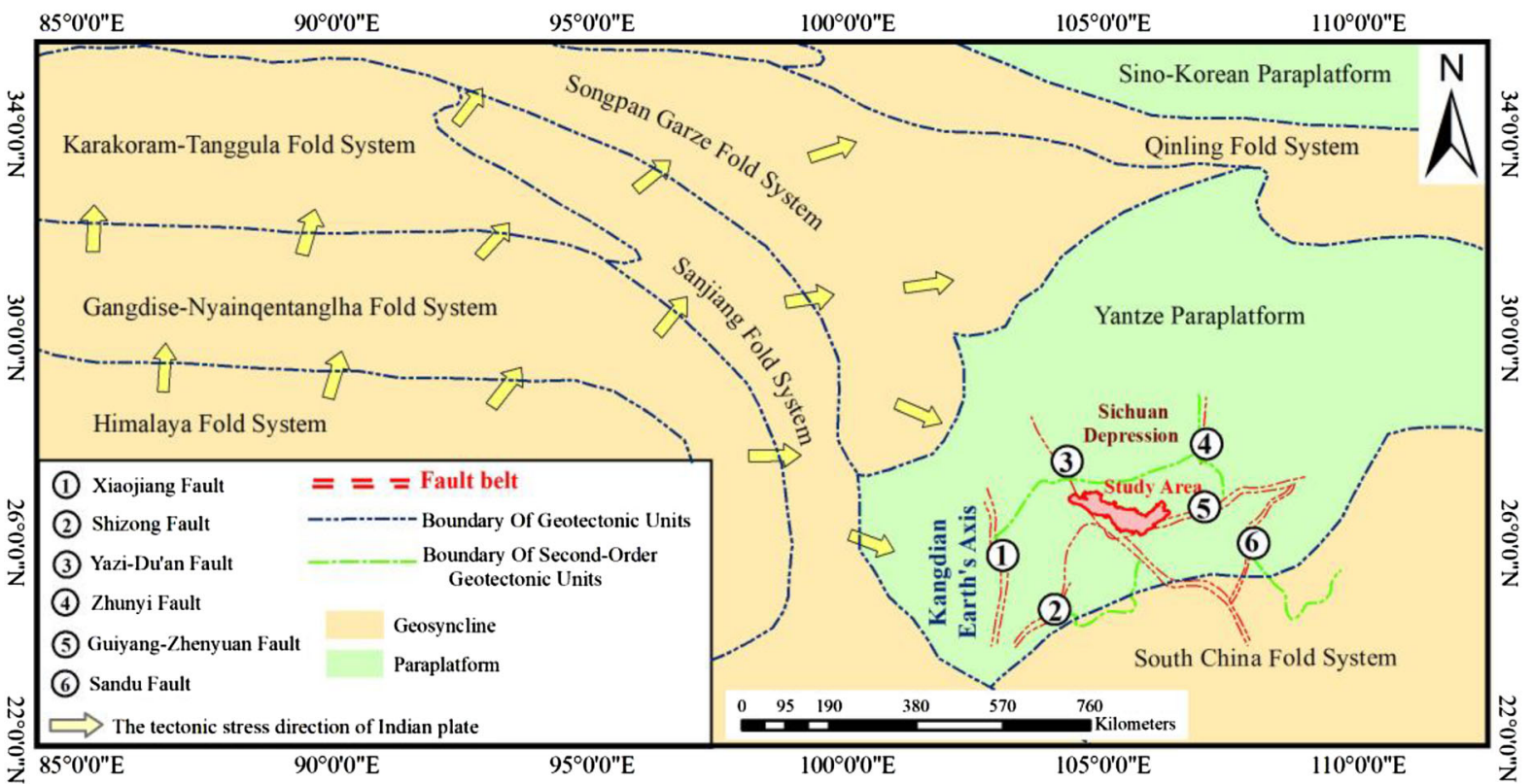

Figure 1. Location map of the Sancha river catchment and main deep faults, main geological units of southwest China.

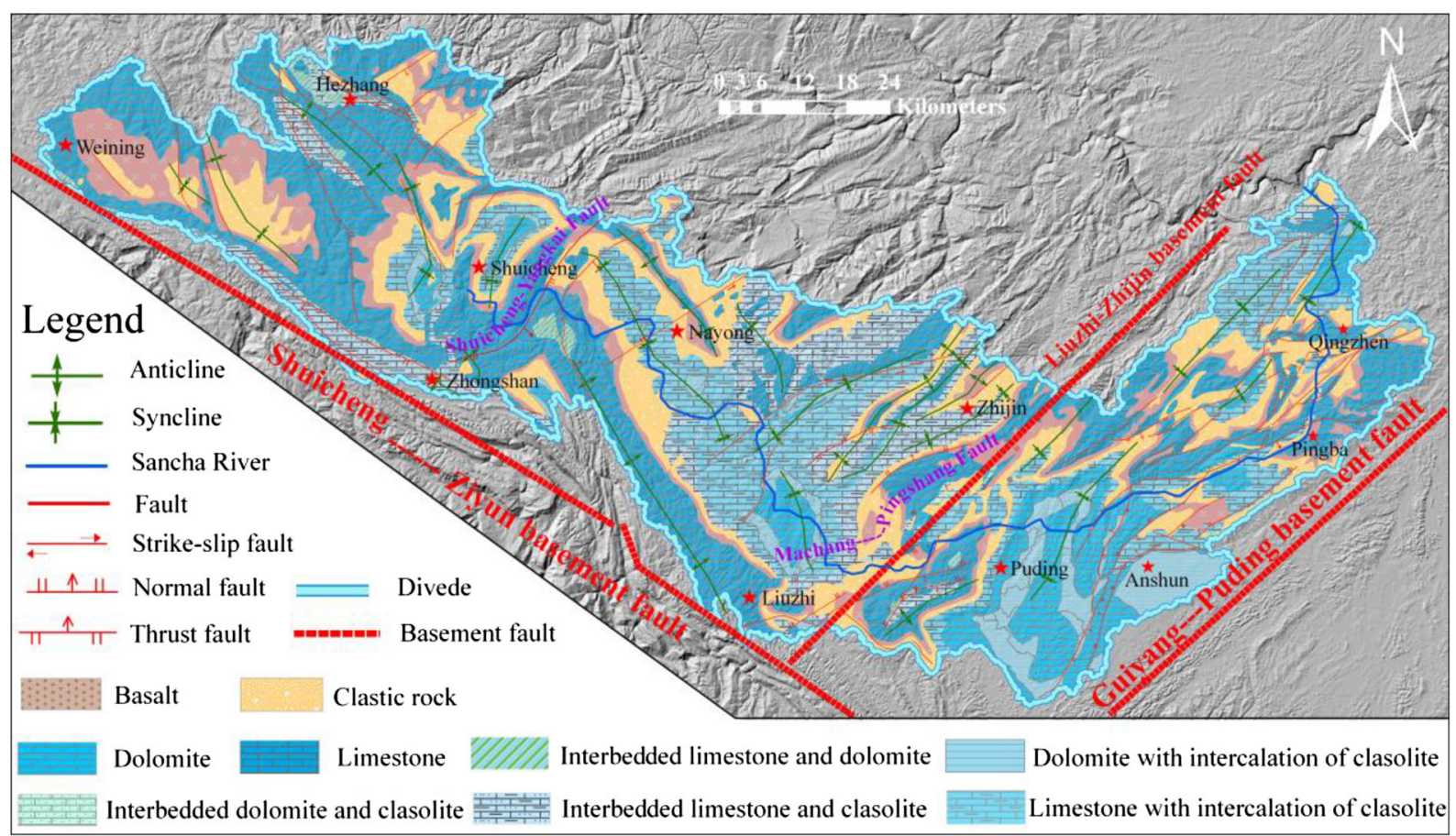

Figure 2. Simplified map showing lithological and major geological structures in the Sancha river catchment.

deformed strongly with the tight folds and associated thrust faults in the contact region of basement fault blocks, and deformed slightly with broad and gentle folds inside the basement fault blocks (Yue et al. 1994).

The catchment includes a large variety of lithologies such as basalt, clastic rocks, limestone and dolomite (figure 2), ranging in ages from Paleozoic to Quaternary. The distribution of different strata is closely related to tectonic evolution. Seen from strata touching relation, the tectonic deformation mainly occurred in the Yanshan movement period that is the period from middle Jurassic to Paleogene (Dou et al. 2012). The Sancha river catchment is located in the combine belt of Tectonic Domains of Tethyan and Peri-Pacific. The study area went 
through the conversion process of stress from the original NE-SW compressional stress to $\mathrm{N}-\mathrm{S}$ one, and then to NW-SE one under the diversion from Tethyan Tectonic Domain to Peri-Pacific one in the mid-episode of Yanshan movement. Thereupon the three direction structures (NE, EW, NE) were formed respectively, which constituted the present structural framework (Dou et al. 2012). During the late Yanshan movement period (from Late Cretaceous to Early Paleogene), parts of thrust faults were transformed into normal ones due to the rapid uplift of the Xuefeng mountain. Large amounts of the NE trending faults are characteristic of leftlateral strike-slip (Qiu et al. 1998; Liu et al. 2010).

As the India Plate, Eurasian Plate and Pacific Plate were in equilibrium from Pliocene to Early Pleistocene, Guizhou earth's crust was in long-term steady state (Lin 1985). The orictocoenosis of Guizhou's neogene has both the charophytes of Tibet and the gastropoda, ostracoda of east China (Lin 1985). The fission track ages of well-crystallized quartz, which was precipitated from Si-rich weathering fluids during the weathering process of carbonate rocks, are from 25 to 1 Ma BP (Liu et al. 2004). All of these chronological evidences indicated that Guizhou's terrain was leveled into the quasi-planation surface, which was known as 'Shanpen period planation surface' under subtropical or tropical conditions (Lin 1985; Cui et al. 1997, 2002). Subsequently, India Plate dived beneath Eurasian Plate intensively, and the strong uplift of Tibetan Plateau gave rise to the tilt-lift of Yunnan-Guizhou Plateau. Bihen movement gave rise to the fold of the Neogene, the closure of the tensional rifts, the significant diverse uplift of fault blocks and the resurgence of the old tectonics during the middle and late Early Pleistocene (Lin 1993). Since the Late Pleistocene, the crust has been in frequent intermittent uplifts. The multilevel river terraces and multilayer karst caves of two sides of valley were developed. The levels of terraces decreased from east to west and the height difference gradually decreased from the old terraces to the new ones (Lin 1993; Zhou and Liu 2005). This phenomenon indicates that the crust in Guizhou Plateau has tilted and uplifted from northwest to southeast and its cycle time of intermittent uplift has constantly shortened since late Early Pleistocene (Zhou and Liu 2005; Kong et al. 2010). The widely distributed planation surfaces have become considerably more difficult to generate during the short stable periods of the crust (Lin 1993; Zhou and Liu 2005).

\section{Methodology}

The original planation surface (Shanpen period planation surface) has deformed by the influence of the uplift and lateral growth of the Tibetan Plateau. Meanwhile, tectonic activity has caused the frequent conversion of hydrodynamic force. All of these have influenced the development and evolution of the landform. Geographic Information System (GIS) was used to analyze the Digital Elevation Model (DEM) that were derived from 1:50000 scale topographic maps. On one hand, the general characteristic and concrete form of neotectonic movement were confirmed by the reconstruction of twisted Shanpen period planation surface, the calculation of the valley floor width-to-height ratio of Sancha river and the analysis of the spatial distribution pattern of river terraces. On the other hand, in order to study the development and evolution of landform at the background of neotectonic movement, the landform was classified through classical geomorphic indicators such as elevation and relief, and hypsometric curves and integrals of the sub-catchments were extracted.

\subsection{The construction of Shanpen period planation surface}

Guizhou crust was in a steady state for a long time under the background of the confluence of India Plate and Pacific Plate from Pliocene to Early Pleistocene. The Shanpen period planation surface, which was once widespread throughout Guizhou was formed ( $\operatorname{Lin} 1985,1993)$. The planation surface is a large-scale landscape and free from the constraint of lithology and tectonic. Red thick layered weathering crust and buried karst are the evidences of wide existence of the planation surface in Guizhou ( $\mathrm{Li}$ et al. 2002). Under the background of crustal uplift in the late period, the base level of erosion has goes down. The mountains have come into being after the headward erosion of waterflow, constantly decomposed the original planation surfaces. The peaks of hills and mountains can be extracted by GIS and anomalous ones can be eliminated through normal QQ plot in Geostatistical Analysis. Based on the peak points, which belong to the Shanpen period planation surface, the twisted Shanpen period planation surface in the study area was reconstructed using Kriging Interpolation Method (figure 3). 


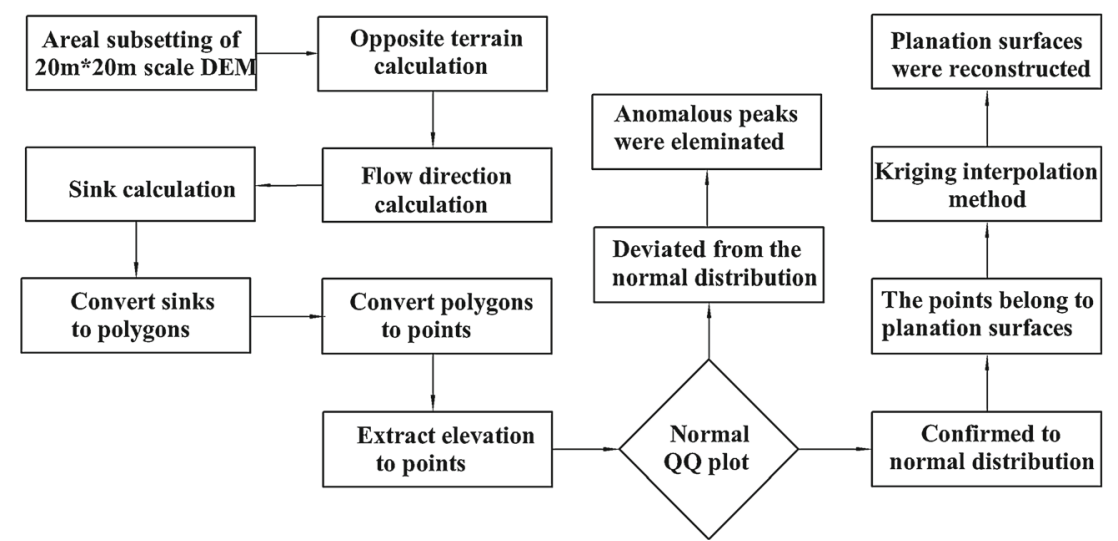

Figure 3. Flow chart of reconstruction for twisted Shanpen period planation surface.

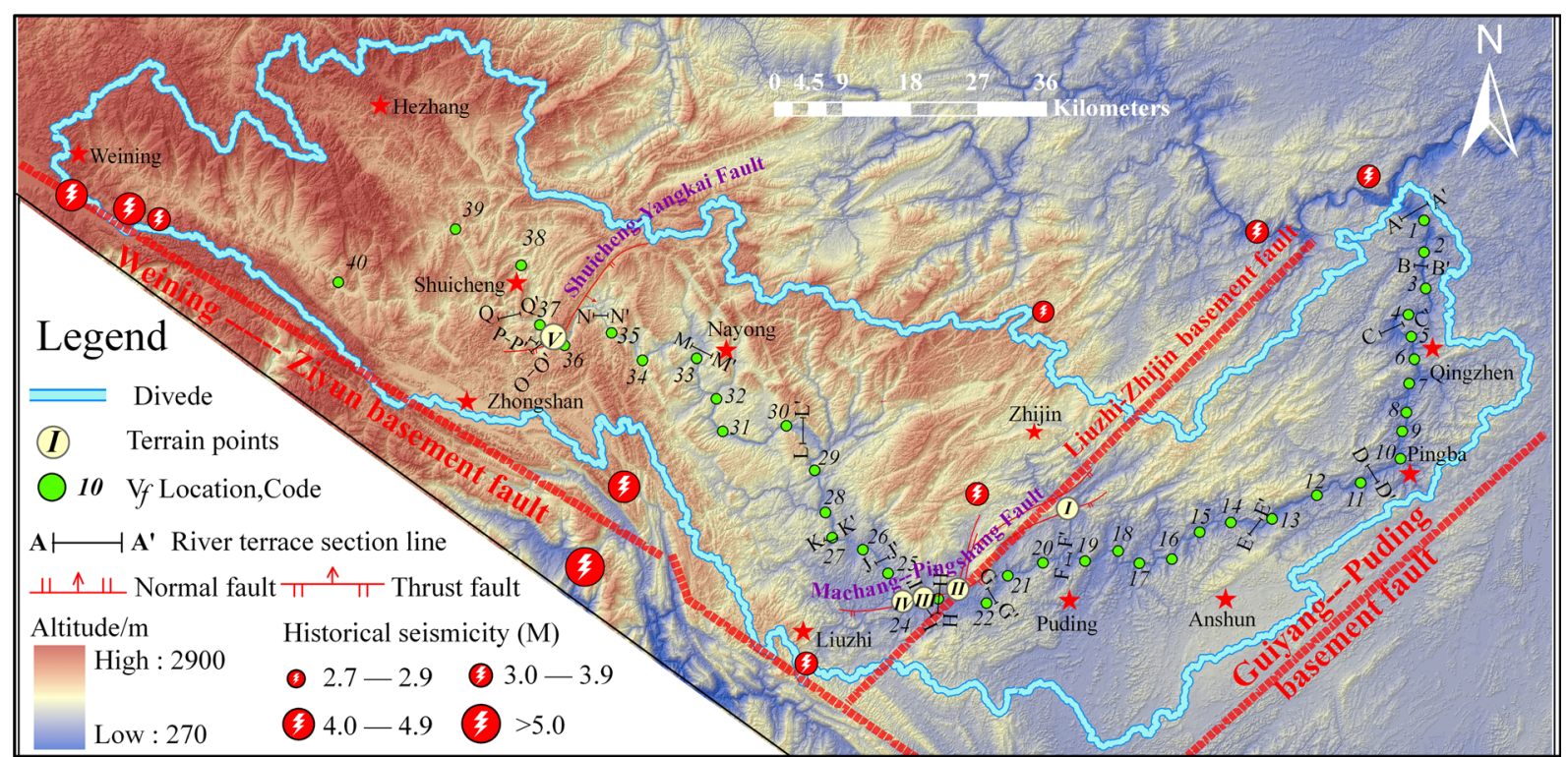

Figure 4. Schematic map showing the locations of the geomorphic indicators measurement and historical earthquakes from 1970 to 2009. The green points are the locations of the $V f$ points which were used to calculate the valley shape of Sancha River. The terrain points (I, II, III, IV, V) reflect the geomorphology of the valleys which traverse the Machang-Pingshang thrust fault and Shuicheng-Yangkai normal fault. The historical seismic data (1970-2009) can be found at http://www.ceic. ac.cn/.

\subsection{Valley floor width-to-height (Vf)}

The development of valley shape is the most direct product of the change of hydrodynamic condition at the background of tectonic activity. Likewise, the spatial variation of valley shape can indicate the tectonic activity. Valley floor width-to-height $(V f)$ is a geomorphic index conceived to discriminate between $\mathrm{V}$-shape and U-shape flat-floored valleys. This index is defined as:

$$
V f=\frac{2 V_{f w}}{E_{l d}+E_{r d}-2 E_{s c}}
$$

where $V_{f w}$ is the width of the valley floor, $E_{l d}$ and $E_{r d}$ are elevations of the left and right valley divides, respectively and $E_{s c}$ is the elevation of the valley floor.

The base level of erosion has gone down due to the crustal uplift, and the valley shape presents the deep V-shape whose $V f$ index is relatively small due to the headward erosion of water-flow. However, the region which has not been affected by the headward erosion of water-flow is shaped by the lateral erosion of the water-flow. So the valley shape presents wide-broad U-shape whose $V f$ index is relatively large (Keller and Pinter 1996; Carter 2010). Based on the high-precision DEM, this paper arranged the sampling points of $V f$ index in the Sancha River (figure 4). The characteristic of neotectonic movement can be 
Table 1. The classification system of landform type ${ }^{a}$.

\begin{tabular}{lccc}
\hline & & Elevation/m & \\
\cline { 2 - 4 } Relief/m & $900 \sim 1600$ (Mid-low) & $1600 \sim 1900$ (Middle) & $1900 \sim 2900($ Mid-high) \\
\hline$<30$ (Basin) & Mid-low basin & Middle basin & Mid-high basin \\
$30 \sim 200$ (Hill) & Mid-low hill & Middle hill & Mid-high hill \\
$201 \sim 500$ & Small relief mid-low & Small relief middle & Small relief mid-high \\
$($ Small relief mountain) & mountain & mountain & mountain \\
$501 \sim 1000$ & Middle relief mid-low & Middle relief middle & Middle relief mid-high \\
$($ Middle relief mountain) & mountain & mountain & mountain \\
\hline
\end{tabular}

Note: ${ }^{a}$ Modified from Gao (2004).

revealed by analyzing the spatial variation of valley shape.

\subsection{Classical landform classification}

This study determined landform classification system for the Sancha river catchment on the basis of classical landform classification. Integrating it with subjective and objective methods, the relief was determined as the subjective factor and the absolute altitude was determined as an objective factor (Gao 2004). So the landform was divided into four categories and twelve subcategories (table 1). This method not only conforms with the human cognition, but also accords with the development law of landform. As the macroscopic geomorphic factor, the relief in the study area was extracted by Neighborhood Analysis based on the $100 \times 100 \mathrm{~m}$ scale DEM. In order to eliminate the scale effect of the relief, the window size of Neighborhood Analysis was determined as $1500 \times 1500 \mathrm{~m}$ through the best window analysis method (Wolock and Mccabe 2015).

\subsection{Hypsometric Integral (HI) of the subcategories}

Hypsometric curves and integrals have long been used as effective indicators of landform evolution (Harlin 1978; Mayer 1990; Pérez-Peña et al. 2010; Gürbüz et al. 2015). $a_{i}$ means the area of catchment above the contour $(i)$, hi means the elevation difference $\left(h_{i}\right)$ between the contour $(i)$ and based one. Define $\mathrm{A}$ and $\mathrm{H}$ as the total area and the total elevation difference of the catchment respectively. Hypsometric curve is created by plotting the relative height $\left(h_{i} / H\right)$ vs. the relative area $\left(a_{i} / A\right)$ (Strahler 1952). Combining HI with the theory of erosion cycle, the evolution stage of landform can be divided according to the following criteria (table 2).

The HI values range from 0 to 1 . Values close to 0 indicate highly eroded tectonically inactive regions, whereas those close to 1 indicate lightly eroded tectonically active regions (PérezPeña et al. 2010). In a tectonically active area (HI values close to 1 ), erosion rate will also be higher and represented by the extent of bedrock incision. HI indicates not only the evolution stage of landform but also the influence of structure, climate, and lithology on it (Keller and Pinter 1996).

\section{Results}

\subsection{The characteristics of neotectonics in the Sancha river catchment}

\subsubsection{The deformation of the original planation surface}

The original planation surface has deformed by the influence of the uplift and lateral growth of the Tibetan Plateau, showing high in northwest, but low in southeast (figure 5). According to generation environment of the red weathering crust of Shanpen period planation surface (Lin 1985; Li et al. 2001), the crustal uplift amplitude may reach 1000-2000 m from northwest to southeast in the study area under the background of neotectonics. The 10 subsidence regions (A, B, C, D, E, F, G, H, I, J) in the study area were formed under the background of syncline. There is an extremely strong spatial consistency between five uplift regions $\left(\mathrm{A}^{\prime}, \mathrm{B}^{\prime}, \mathrm{C}^{\prime}, \mathrm{D}^{\prime}, \mathrm{E}^{\prime}\right)$ and the anticlines (figure 5). These folds were almost formed in the Yanshan movement. So this phenomenon indicates the resurgence of tectonic deformation of the Yanshan in the neotectonic period. Liuzhi-Zhijin basement fault and Weining-Ziyun 
Table 2. The classification standard of the landform evolution stage ${ }^{a}$.

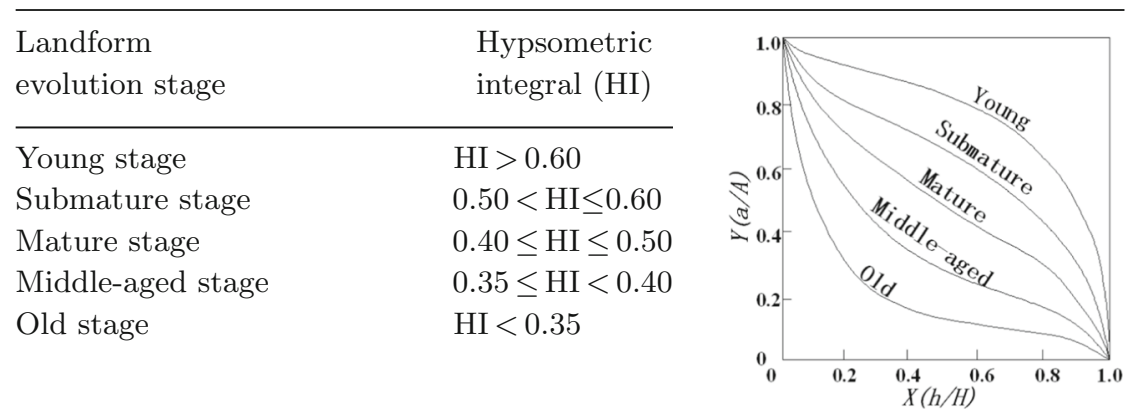

Note: ${ }^{a}$ Modified from Sun $(2005)$.

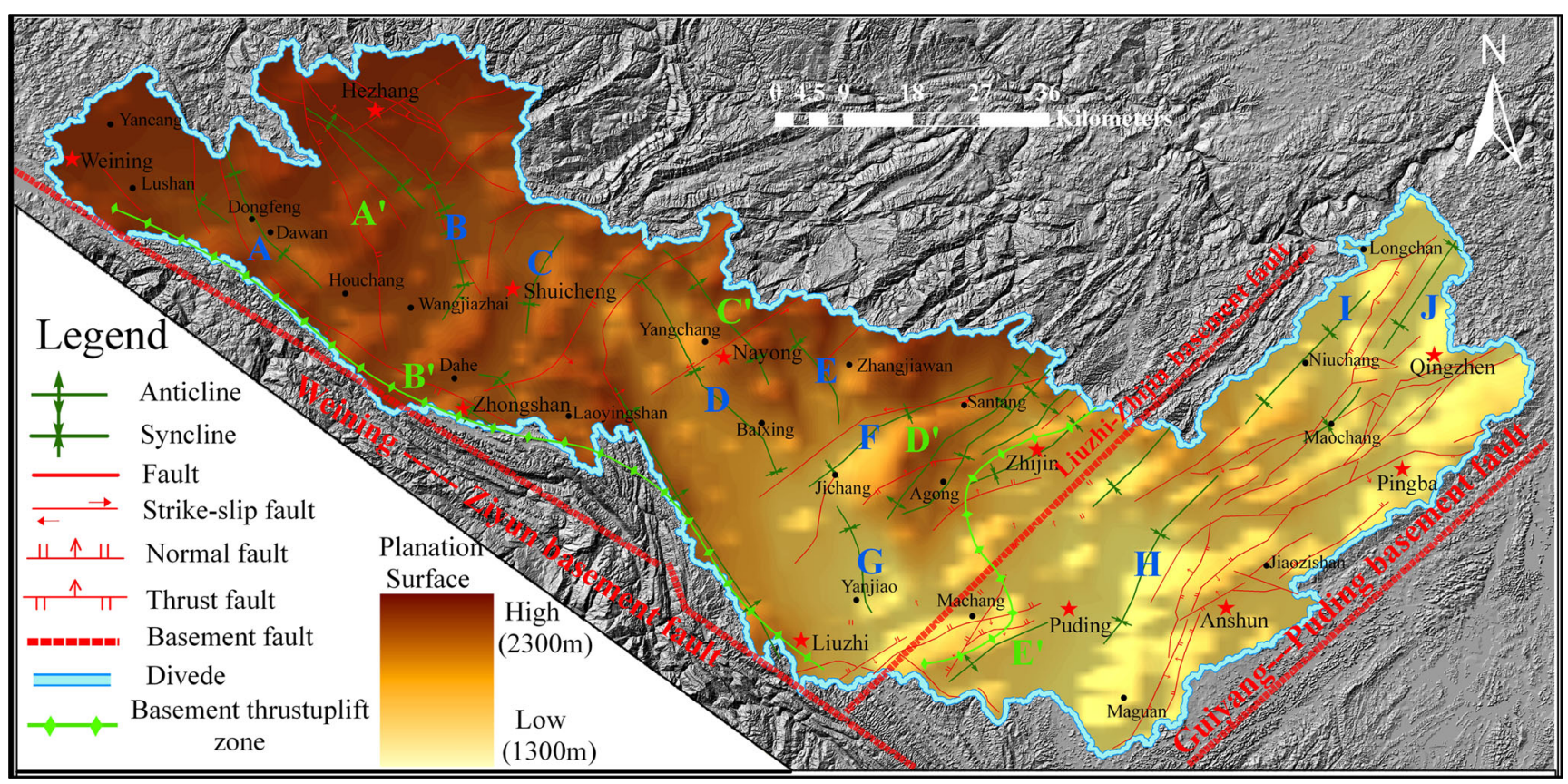

Figure 5. The distribution map of the Shanpen period planation surface at middle-late Pleistocene. The blue letters (A, B, C, D, E, F, G, H, I, J) represent the subsidence regions, which have good consistent with the synclines. The green letters $\left(\mathrm{A}^{\prime}, \mathrm{B}^{\prime}, \mathrm{C}^{\prime}, \mathrm{D}^{\prime}, \mathrm{E}^{\prime},\right)$ represent the uplift regions, which have good consistent with the anticlines.

basement fault became stress concentration belts and showed inherited movement under pressures of the Tibetan Plateau and also, their covers folded strongly and formed basement thrust uplift zones (figure 5).

\subsubsection{The spatial variation of valley shape of Sancha River}

The valley shape can reflect hydrodynamic condition and indicate tectonic activities. The $V f$ values of Sancha River increase constantly from downstream to Liuzhi-Zhijin basement fault. It presents that the valley shapes transit from $\mathrm{V}$-shape to U-shape. The $V f$ values first decrease and then increase from Liuzhi-Zhijin basement fault to upstream. It indicates that the valley shape transits from U-shape to V-shape and then back to U-shape (figure 6). This spatial variation of the valley shapes indicates that the fault blocks uplift differently on both sides of Liuzhi-Zhijin basement fault. And the Sancha river catchment was broken into two relative independent landform units.

The posthumous activity of the Liuzhi-Zhijin basement fault has caused the activities of the Machang-Pingshang thrust fault in the neotectonic period, and the hydrodynamic condition of Sancha River has been changed. The footwall became the new erosion base level of hanging wall due to 


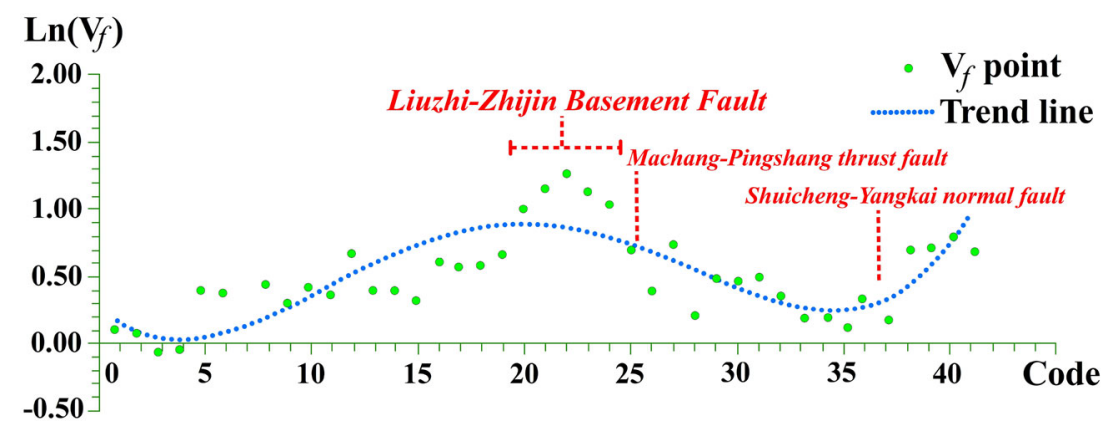

Figure 6. Plot of Vf values for Sancha River. Points' code are shown in figure 4.

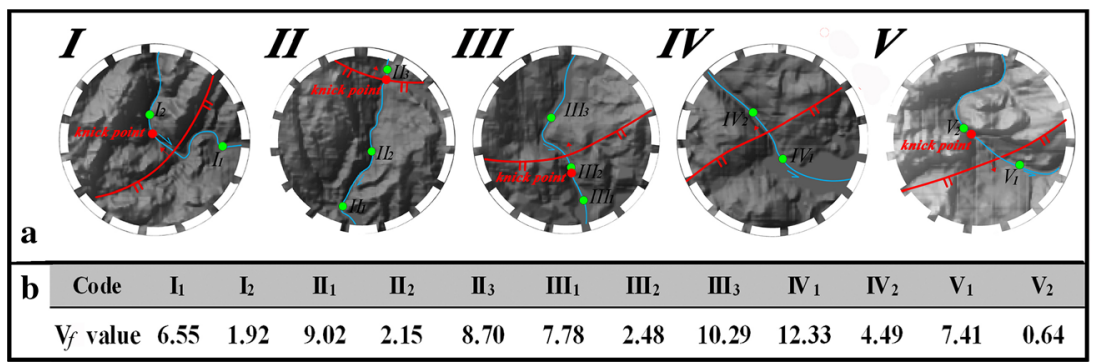

Figure 7. The valleys' feature map of terrain points. (a) Physiographic map of the terrain points (green points show the locations of $V f$ measurements, red points mark knick points of the rivers, blue lines show the rivers which traverse the faults). (b) The values of $V f$ measurements. The $V f$ values gradually increase from I to IV.

the activity of Machang-Pingshang thrust fault. The headward erosion has gone deep from the lowest point of Sancha River and Machang-Pingshang thrust fault, respectively, under the background of fault blocks' different uplift. Because the headward erosion has not gone into, the footwall of the Machang-Pingshang thrust fault keeps broad and gentle the valley, which is characterized by the highest $V f$ value in the whole region (figure 6 ). The hanging wall of Machang-Pingshang thrust fault has been downcut and characterized by V-shaped valley.

This spatial variation of the valley shape also appears at both sides of the Shuicheng-Yangkai normal fault, which might inverse from the thrust fault of Yanshan period. Due to the relative descent of the hanging wall, the valley shape presents U-shaped under the action of lateral and downward erosion. Uplift of the footwall has led to the enormous deepening of riverbed, and the valley shape is characterized by $\mathrm{V}$-shaped valley and lower $V f$ value. However, the valley shape converts into broad and gentle U-shaped valley not far from Shuicheng-Yangkai fault to the upstream. This phenomenon indicates that the start time of Shuicheng-Yangkai normal fault activity is relatively later than Machang-Pingshang thrust fault.
The northwest of the fault reserves the tectonic denudation landform because the headward erosion has not gone deep into.

Valley shape is sensitive to the tectonic activity. The work presented here analyzed the activity of Machang-Pingshang thrust fault and ShuichengYangkai normal fault by the shapes of valleys which transect the faults. The terrain feature points (I, II, III, IV) distribute along the Machang-Pingshang thrust fault from the northeast to the southwest (figure 4). The valley shapes in uplifted and downthrown walls of the fault have obvious differences. The valley shapes present high and cliffy $\mathrm{V}$-shape in the uplift wall, and broad and gentle U-shape in the downthrow wall. This phenomenon reflects the activity of Machang-Pingshang thrust fault in the neotectonic period. Besides, the valleys are characterized by river knickpoints in the I, II, III except IV (figure 7a), and the $V f$ values increase from northeast to southwest along the Machang-Pingshang thrust fault (figure $7 \mathrm{~b}$ ). These indicate that the activity of the fault has diminished from northeast to southwest. We reckon that the inherited activity of the Weining-Ziyun basement fault may limit the activity of the southwest part of Liuzhi-Zhijin basement fault. Compared to the valleys' features in the IV and V, the 
$V f$ values of $\mathrm{V}$ is lower than IV and is characterized by river knick point (figures 4 and 7 ). It reflects that the current activity of the fault in $\mathrm{V}$ is stronger than that in IV.

\subsubsection{The spatial distribution pattern of the river terraces}

Repeated episodes of down-cutting have resulted in the formation and preservation of the river terraces due to intermittent uplifts of crust and climatic change. Surviving degree of river terraces varies under the action of exogenic process. In this work, we have selected the valleys where the terraces developed and remained well as the sampling points, and the cross-sections were made normal to the valleys (figure 4). The Sancha river catchment can be divided at Liuzhi-Zhijin basement fault and Shuicheng-Yangkai normal fault into three subareas. Each subarea has similar spatial distribution pattern of river terraces with terrace series decreasing from downstream to upstream. This pattern can be seen from $\mathrm{A}-\mathrm{A}^{\prime}$ to $\mathrm{I}-\mathrm{I}^{\prime}, \mathrm{J}-\mathrm{J}^{\prime}$ to $\mathrm{M}-\mathrm{M}^{\prime}$ and $\mathrm{N}-\mathrm{N}^{\prime}$ to $\mathrm{Q}-\mathrm{Q}^{\prime}$ and indicates the controlling action of headward erosion of water-flow on the development of river terrace under the background of intermittent uplift of crust (figure 8; table 3). Four levels of river terraces have been developed in the southeast lateral subarea of Liuzhi-Zhijin basement fault (figure $8 \mathrm{~A}-\mathrm{A}^{\prime}, \mathrm{B}-\mathrm{B}^{\prime}$ ), which provides an indication that the study area has experienced at least four intermittent uplifts. The combination of the multiple spatial distribution patterns shows differential uplifts of fault blocks. The three levels of river terraces have been developed in the northwest lateral subarea of Liuzhi-Zhijin basement fault, which indicates that the fault blocks have experienced three differential uplifts at both sides of Liuzhi-Zhijin basement fault (figure 8J- $\mathrm{J}^{\prime}$, $\left.\mathrm{K}-\mathrm{K}^{\prime}, \mathrm{L}-\mathrm{L}^{\prime}\right)$. Compared to the relative elevation of the same level of river terraces in the $\mathrm{N}-\mathrm{N}^{\prime}$, that of $\mathrm{O}-\mathrm{O}^{\prime}$ has been risen rapidly (figure $8 \mathrm{~N}-\mathrm{N}^{\prime}, \mathrm{O}-$ $\left.\mathrm{O}^{\prime}\right)$. This indicates that Shuicheng-Yangkai normal fault has experienced at least one intense activity. However, because the time of its activity is relatively late and headward erosion of water-flow has not gone deep, no river terraces have developed in the $\mathrm{Q}-\mathrm{Q}^{\prime}$ (figure $8 \mathrm{Q}-\mathrm{Q}^{\prime}$ ).

The earthquakes are mainly distributed on Weining-Ziyun basement fault, Liuzhi-Zhijin basement fault and their surrounding regions according to the historical seismic data, which was recorded from 1970 to 2009 (figure 4). However, the region surrounding Shuicheng-Yangkai normal fault does not have historical seismic records with magnitudes $>2.5 \mathrm{M}$. This may relate to the active fault's property. The activities of normal fault release energy gradually in the tension stress field, but the thrust is quake-prone due to the abrupt release of the accumulated energy (Cocco and Rovelli 1989).

\subsection{The landform development under the background of neotectonics}

Crustal tilt-lift of Sancha river catchment and the posthumous activity of Yanshan structure have controlled the modern landform development during the neotectonic period. The posthumous activity of Liuzhi-Zhijin basement fault has resulted in the resurgence of Machang-Pingshang thrust fault which broke the Sancha river catchment into two relatively independent landform units. The crustal uplift has changed hydrodynamic conditions which shaped the landform, especially in the region near the Sancha river. And the region was divided into four sub-regions $\left(\mathrm{I}_{1}, \mathrm{I}_{2}, \mathrm{II}_{1}\right.$, $\mathrm{II}_{2}$ ) according to the influence of headward erosion on landform development (figure 9). From downstream to upstream, the spatial variation of the landform presents periodic replacement, which shows the transition from small relief mountain $\left(\mathrm{I}_{1}\right)$ to basin and hill $\left(\mathrm{I}_{2}\right)$, and from then small relief mountain $\left(\mathrm{I}_{3}\right)$ to basin and hill $\left(\mathrm{I}_{4}\right)$ (figure 9).

The frequency of crustal intermittent uplift has been accelerating since the Late Pleistocene (Lin 1993; Zhou and Liu 2005). The water-flow has downcut the surface along the original river way. The landform development of the region, far away from Sancha River, has lagged behind that of the region near the valley. There are good spatial coincidence between landform types and the styles of geological structure (figure 9). The partition wall style fold-thrust belt was widely developed in the southeast lateral of the Liuzhi-Zhijin basement fault, and the layers are almost horizontal in the core region of trapped synclines. The landform types mainly show mid-low basin and mid-low hill such as $\mathrm{A}_{1}, \mathrm{~A}_{2}, \mathrm{~A}_{3}$, and $\mathrm{A}_{4}$. During the neotectonic period, the area near basement fault became the stress concentration area. The cover has folded strongly and the associated fault developed well. The activity of thrust fault in the cone of the anticlines has resulted in the exposure of the Early Paleozoic strata, which is characterized by the 

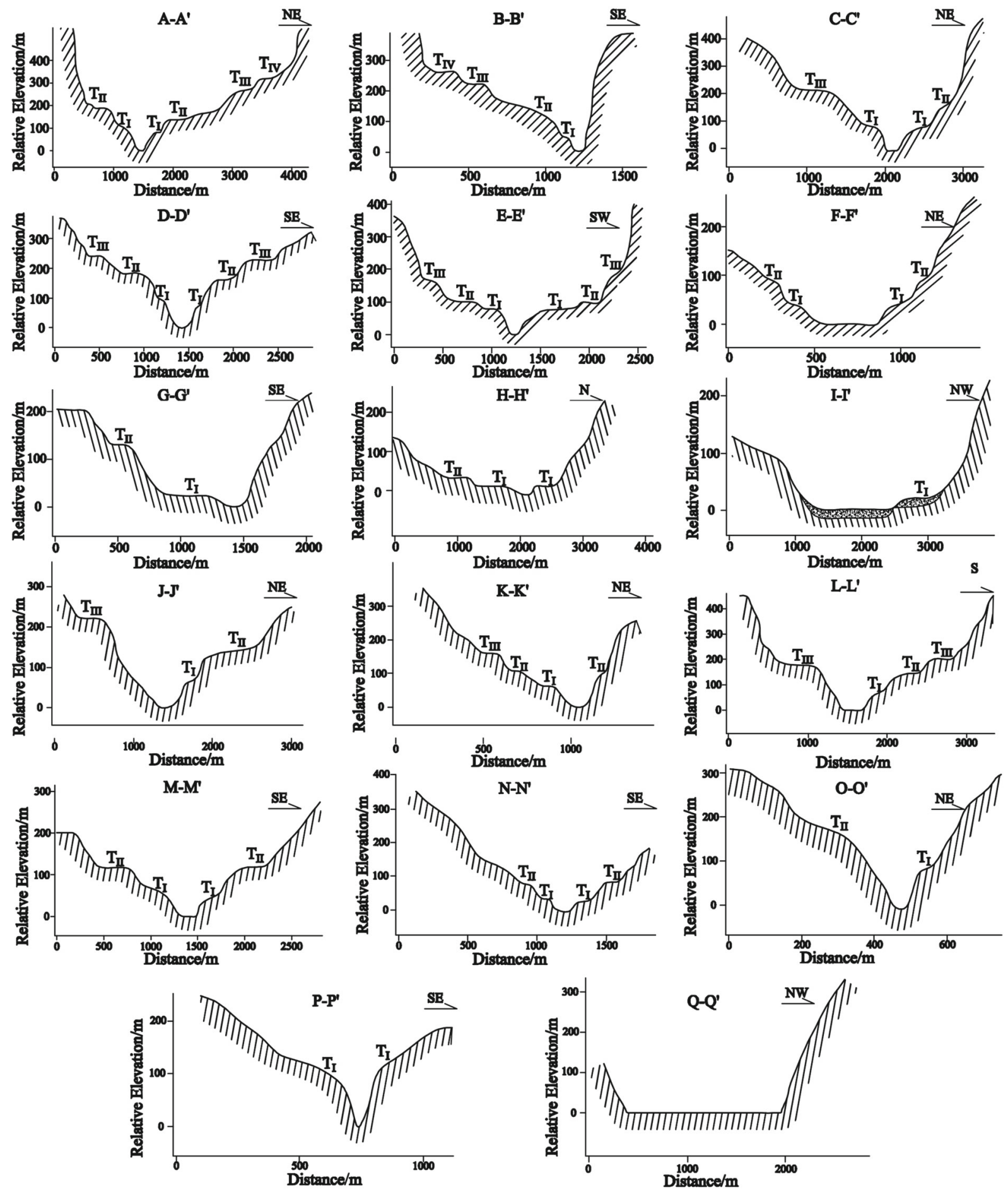

Figure 8. Valley profile marking the terraces $\left(\mathrm{T}_{\mathrm{I}}, \mathrm{T}_{\mathrm{II}}, \mathrm{T}_{\mathrm{III}}, \mathrm{T}_{\mathrm{IV}}\right)$. Cross-sections were made across the Sancha River (figure 4 ). Relative elevation refers to the elevation of terrace relative to riverbed.

Table 3. The comparison of relative elevation of river terraces in the Sancha River.

\begin{tabular}{|c|c|c|c|c|c|c|c|c|c|c|c|c|c|c|c|c|}
\hline Terrace & $A-A^{\prime}$ & B-B' & $\mathrm{C}-\mathrm{C}^{\prime}$ & $\mathrm{D}-\mathrm{D}^{\prime}$ & $\mathrm{E}-\mathrm{E}^{\prime}$ & $\mathrm{F}-\mathrm{F}^{\prime}$ & $G-G^{\prime}$ & $\mathrm{H}-\mathrm{H}^{\prime}$ & $\mathrm{I}-\mathrm{I}^{\prime}$ & $\mathrm{J}-\mathrm{J}^{\prime}$ & $\mathrm{K}-\mathrm{K}^{\prime}$ & L-L' & $\mathrm{M}-\mathrm{M}^{\prime}$ & $\mathrm{N}-\mathrm{N}^{\prime}$ & $\mathrm{P}-\mathrm{P}^{\prime}$ & $\mathrm{Q}-\mathrm{Q}^{\prime}$ \\
\hline$\Gamma_{I V}$ & 320 & 270 & - & - & - & - & - & - & - & - & - & - & - & - & - & - \\
\hline $\mathrm{T}_{\text {III }}$ & 270 & 215 & 215 & 225 & 180 & - & - & - & - & 220 & 165 & 180 & - & - & - & - \\
\hline $\mathrm{T}_{\mathrm{II}}$ & 160 & 135 & 165 & 170 & 120 & 90 & 120 & 30 & - & 140 & 105 & 140 & 120 & 160 & - & - \\
\hline $\mathrm{T}_{\mathrm{I}}$ & 90 & 60 & 85 & 80 & 85 & 40 & 20 & 15 & 20 & 70 & 60 & 30 & 30 & 80 & 100 & - \\
\hline
\end{tabular}




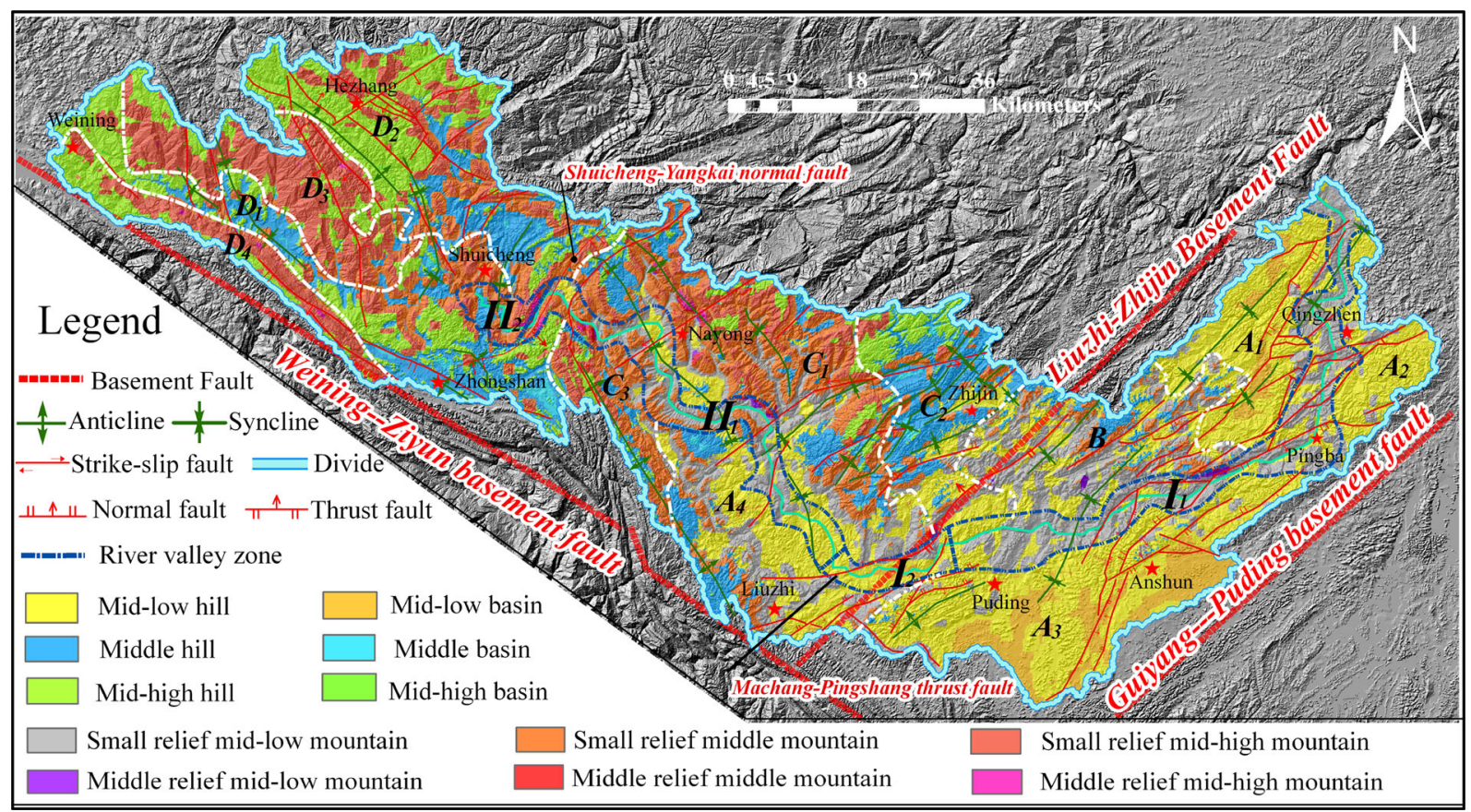

Figure 9. Landform classification map of the study area. The region near the Sancha River was divided into four subregions $\left(\mathrm{I}_{1}, \mathrm{I}_{2}, \mathrm{II}_{1}, \mathrm{II}_{2}\right)$. And the region which is far away from the Sancha River was divided into several subregions such as $\mathrm{A}_{1}$, $\mathrm{A}_{2}, \mathrm{~A}_{3}, \mathrm{~A}_{4}, \mathrm{~B}, \mathrm{C}_{1}, \mathrm{C}_{2}, \mathrm{C}_{3}, \mathrm{D}_{1}, \mathrm{D}_{2}, \mathrm{D}_{3}, \mathrm{D}_{4}$.

soaring mountains. Meanwhile, the faults became the weak structure surfaces, which were strongly corroded by the water-flow. So they are characterized by the long and deep valleys. Therefore, the regions near the basement fault mainly show small relief mid-low mountain such as B. The geological structure mainly presents wavy fold under the activity of Weining-Shuicheng basement fault and Liuzhi-Zhijin basement fault in the northwest lateral of the Liuzhi-Zhijin basement fault. The landform is characterized by geologic structure which presents anticlinal mountain and synclinal valley. Meanwhile, the water-flow has downcut the surface along the original riverway under the background of crustal uplift. So the landform mainly presents high mountain and deep valley such as $\mathrm{C}_{1}$. The region in which the headward erosion of water-flow has not gone into is characterized by denudational landform that presents gentle mid-high hill and middle hill such as $\mathrm{C}_{2}$ and $\mathrm{C}_{3}$. Likewise, the headward erosion of Sancha River has not gone deep into the Weining, Hezhang and Zhongshan due to the activity of the Shuicheng-Yangkai normal fault. Therefore, the general terrain not only possesses the characteristic of consequent relief, but also is characterized by the Shanpen period planation surface $\left(D_{1}, D_{2}\right)$. The slope zones $\left(D_{3}, D_{4}\right)$ between the synclinal basin and anticlinal mountain mainly have shown small relief mid-high mountain due to the erosion of water-flow.

\subsection{The landform evolution under the background of neotectonics}

The landform evolution is the product of the coupling effect between endogenic and exogenic geological processes. The landform rejuvenates as the base level of erosion goes down. The landform can rejuvenate from any evolutionary stage under the background of the crustal uplift (Bishop 2010; Quigley 2017). The intermittent uplift and expansion of Tibetan plateau have resulted in the crustal tilt-lift of the study area from northwest to southeast during the neotectonic period. The rejuvenation of landform has shown obvious spatial variation pattern due to differential uplift of the fault blocks in the Sancha river catchment. This paper discussed the influence of neotectonic movement on the landform evolution by the extraction of the Hypsometric Integral (HI) of subcatchments.

According to the extraction of HI, the evolutionary stages of the subcatchments present periodic replacement. It transits from mature stage to young stage, and from sub-mature stage and the mature stage to the young stage again along the downstream towards the upstream. Seeing the Liuzhi-Zhijin basement fault as the boundary, the 


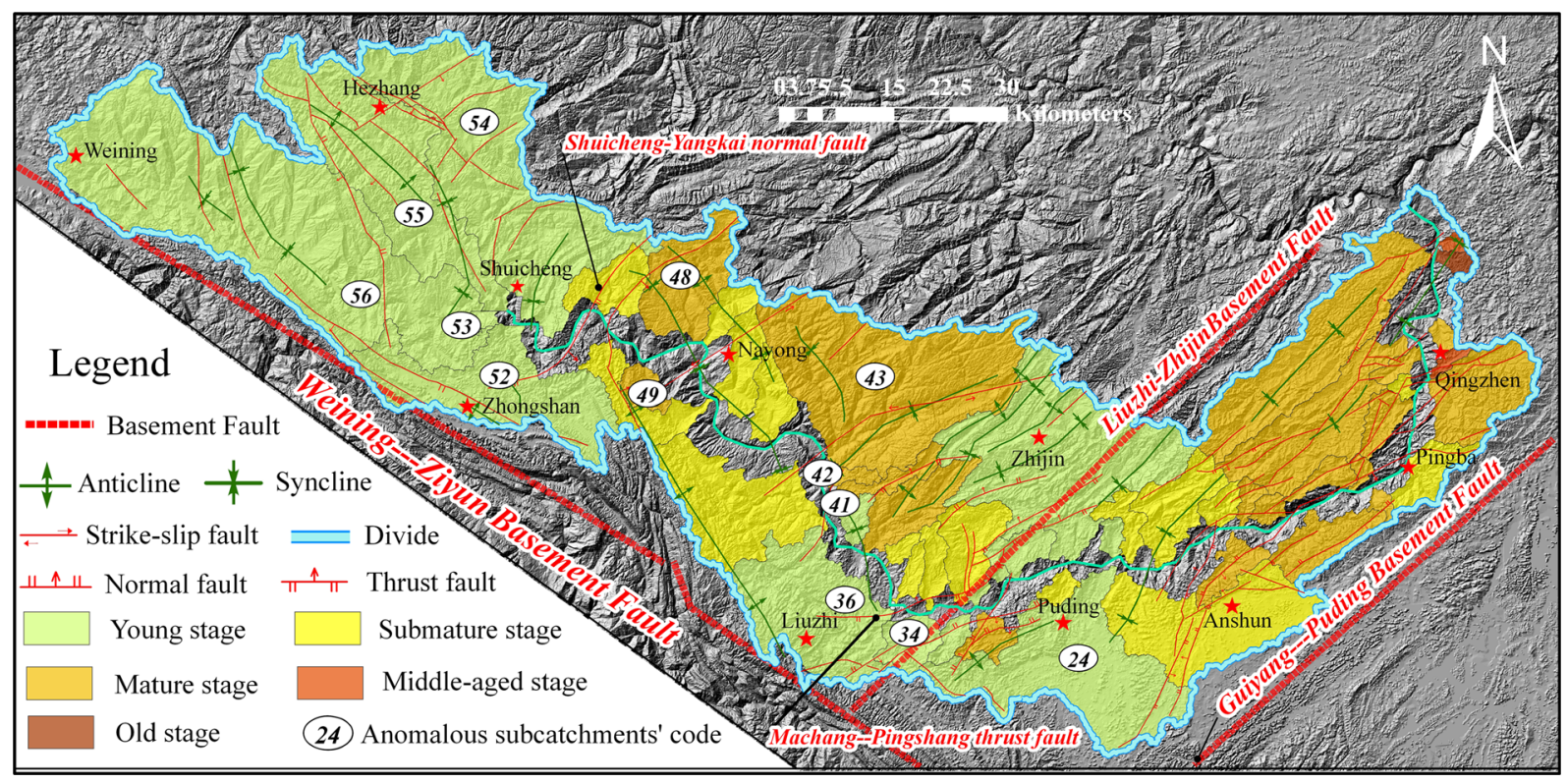

Figure 10. Landform evolution stage map showing the spatial variation of the Sancha river catchment. Seen Zhijin-Liuzhi basement fault as boundary, Sancha river catchment was divided into two evolution cycles, which transited from mature stage to young stage.

spatial differentiation of the landform evolution can be divided into two cycles, i.e., from the mature stage and the sub-mature stage to the young stage (figure 10). The spatial replacement of subcatchments' landform evolution has basically reflected the controlling action of headward erosion on landform evolution at the background of the differential uplift of the fault blocks. On the whole, the HI values of the northwest lateral of the Liuzhi-Zhijin basement fault are larger than those of southeast lateral (figure 11). And the HI values of the northwestern lateral of ShuichengYangkai normal fault are largest in the whole study area. This result squares with the characteristics of the neotectonic movement that has been well documented as above. The uplift amplitude of the fault blocks has decreased in the southeast direction under the background of the uplift and compression of Tibetan Plateau. These neotectonic characteristics have resulted in, where the landform evolutionary stage of the northwestern fault block is younger than that of the southeastern one. And the recent activity of Shuicheng-Yangkai normal fault has resulted in its northwestern lateral subcatchments becoming the youngest landform region in the study area, such as $\mathrm{U}_{3}$ (figure 11).

Geological structure and geological framework are also the important factors that affect the landform evolution process, thus giving rise to the local exceptions from the spatial variation of periodic replacement. Anshun and Puding are located in the core of broad and gentle syncline and retain peneplain in geomorphology, which are composed of thick carbonatite with intermediate clasolite. There is no hydraulic connection between the landform development and the deepcutting Sancha River because of the barrier action of clasolite. So the landform evolution has a relatively slow rate and is characterized by the relatively large HI values under the background of the crustal uplift, such as $\mathrm{U}_{1}$ (figure 11). The Liuzhi region lies in the convergence zone of Liuzhi-Zhijin basement fault and Weining-Ziyun basement fault. The earth's crust in this area has been uplifted more sharply, so that the subcatchments also have relatively large $\mathrm{HI}$ values such as $\mathrm{U}_{2}$ (figure 11 ). The posthumous activities of syncline have neutralized the rejuvenation of landform evolution at the background of crustal uplift, which have reduced the $\mathrm{HI}$ values of sub-catchments such as $\mathrm{D}_{1}, \mathrm{D}_{2}$ (figure 11).

\section{Discussion}

The collision of the India Plate with the Eurasia Plate has played a leading role in the tectonic stress field of Southwest China since Mesozoic (Armijo et al. 1986; Ratschbacher et al. 1992). Especially from the Early Pleistocene to the Middle Pleistocene, the India Plate has been continuously 


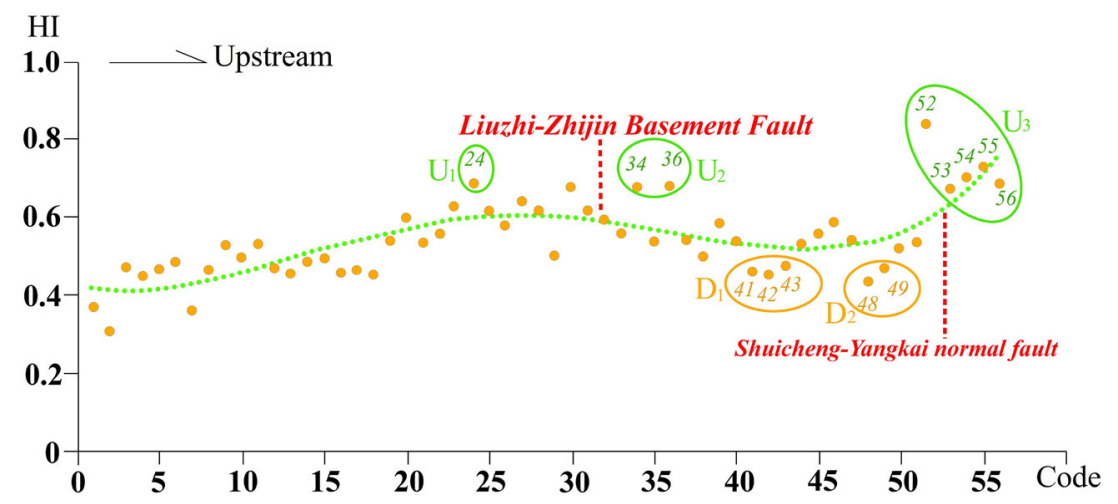

Figure 11. The spatial variation map of the subcatchments' HI values. Geological structure and geological framework gave rise to the local exceptions $\left(\mathrm{U}_{1}, \mathrm{U}_{2}, \mathrm{U}_{3}, \mathrm{D}_{1}, \mathrm{D}_{2}\right)$ from the spatial variation of periodic replacement.

thrusted northward and the Eurasia and Tibetan Plateau have been disintegrated into fault blocks (Xu and Zhao 2006; Ping 2012). As a result of the southeastward extrusion of the Tibetan Plateau, the tectonic stress field of Guizhou whose direction of principal stress is WNW-ESE direction, has been formed and continued to this day (Xie et al. 1999; Wan 2010). Due to the southeastward extrusion of the Tibetan Plateau, the crust of Sancha river catchment has tilted from the northwest to southeast as a concrete manifestation of fault blocks in different amounts of uplifts. This has caused the hydrodynamic condition to transform frequently during water-flow movement. Based on the Bernoulli equation:

$$
\begin{aligned}
a v_{1}^{2} / 2 g+Z_{1}+h w_{1} & =a v_{2}^{2} / 2 g+Z_{2}+h w_{2} \\
& =a v_{3}^{2} / 2 g+Z_{3}+h w_{3} \\
& =a v_{4}^{2} / 2 g+Z_{4}+h w_{4}
\end{aligned}
$$

where $\alpha$ is head loss coefficient; $v_{1}, v_{2}, v_{3}, v_{4}$ respectively are water velocity of $1,2,3,4 . Z_{1}, Z_{2}, Z_{3}, Z_{4}$ respectively are the water level elevation of 1,2 , 3,4 and $h w_{1}, h w_{2}, h w_{3}, h w_{4}$ are respectively the head loss of $1,2,3,4$. Gravitational acceleration is denoted as $g$ (figure 12a).

The big height gaps of the terrains were formed in the marginal areas of the fault blocks due to the differential uplifts of fault blocks. The water-flows converted potential energy, which was obtained from the uplift of the earth's crust into kinetic energy at the edges of fault blocks. Stream erosion is incision-based and canyons have been formed. Because the headward erosion of downstream water-flows has not gone into the insides of the fault blocks, stream erosion is lateral erosionbased and the valleys present wide and broad shape
(Babault et al. 2007; figure 12b). The difference of lithologies can also cause the spatial variation of valley shapes (Dufresne et al. 2016), but it is impossible to make it be characterized by periodic replacement. The spatial variation of Sancha River's valley shape indicates that the LiuzhiZhijin basement fault divided the Sancha river catchment into two landform units (figure 12b).

The landform development is the common product of stratum lithology, geological structure and external forces. These three have different effects on the landform development in different areas (Cyr et al. 2014; Gürbüz et al. 2015). The landform development of the region near the valley has been controlled by the change of the hydrodynamic condition caused by tectonic activity (Pérez-Peña et al. 2010), and this manifests as spatial variation of valley shape. Because the headward erosion of water-flow has not gone deep into, the landform development of the region, which is far away from the valley is controlled by the styles of geological structure. The spatial consistency of landform types and the styles of geological structures is obvious. Meanwhile, different stratum lithologies have different anti-erosional abilities, higher the shale content, weaker is the erosion (Bahrami et al. 2015; Goudie 2016). So most of broad and gentle valleys and basins were formed in mudstone areas. Instead, the high and cliffy valleys were formed in carbonate areas.

Landform evolution of subcatchments is closely related to the different amounts of crustal uplifts (Lifton and Chase 1992; Gürbüz et al. 2015; Sarp 2015; Partabian et al. 2016), therefore, the spatial variation of subcatchments' landform evolution is characterized by periodic replacement. However, the landform evolution of catchment has not only been controlled by the overall tectonic framework, 


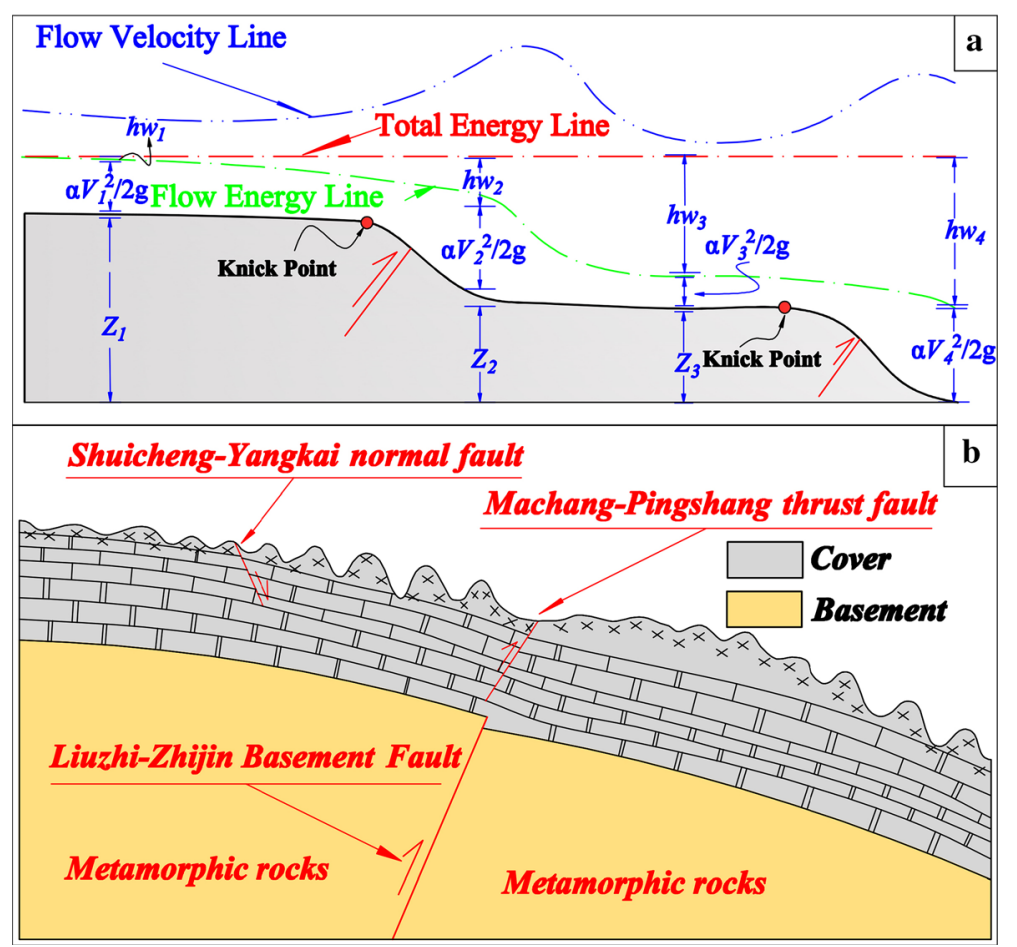

Figure 12. Schematic map of landform development in the Sancha river catchment. (a) Schematic map of energy conversion in the course of the water movement. $\alpha$ is head loss coefficient. $\mathrm{V}_{1}, \mathrm{~V}_{2}, \mathrm{~V}_{3}, \mathrm{~V}_{4}$, respectively are water velocity of 1 , 2, 3, 4. $Z_{1}, Z_{2}, Z_{3}, Z_{4}$ respectively are the water level elevation of $1,2,3,4$. $h w_{1}, h w_{2}, h w_{3}, h w_{4}$ are respectively the head loss of $1,2,3,4$. Gravitational acceleration is denoted as $g$. (b) Schematic map of landform in the Sancha river catchment. The Liuzhi-Zhijin basement fault divided the Sancha river catchment into two landform units.

but also influenced by the posthumous activity of the secondary structures in the subcatchments (Gürbüz et al. 2015). The posthumous activity of syncline and the subsidence of fault blocks have neutralized the rejuvenation of landform evolution at the background of crustal uplift, which has given rise to the subcatchments' landform evolution in the relatively old stage. However, the posthumous activity of anticline and the uplift of fault blocks have further enhanced the rejuvenation of landform evolution, which has given rise to the subcatchments' landform evolution in the relatively young stage. Therefore, the spatial variation of subcatchments' landform evolution has shown the spatial distribution of periodic replacement with local exceptions.

This study analyzed the general characteristics and concrete form of the neotectonic movement and quantified the development and evolution of landform by the application of geomorphic indices, and then revealed the characteristics of the spatial variation of landform development and evolution under the background of neotectonic movement. In this study, we have further researched the responsive mechanism of landform to the tectonic activity and provided a new idea for the activity appraisal of crust. However, the characteristic of strike slip of the fault could not be identified, which has been mentioned earlier (Feng et al. 2007; Wan et al. 2008; Dou et al. 2012). The drainage offset can therefore be used to evaluate tectonic deformations on horizontal axis in the future study (Gürbüz et al. 2015). The river terrace indicates the intermittent uplift of the crust during the neotectonic period (Lin 1993; Zhou and Liu 2005). This study analyzed the intermittency of the neotectonic movement of Sancha river catchment by the spatial distribution pattern of river terraces. However, the chronology study and field investigation of river terraces at different levels have not been carried out yet and therefore, the formation age and pattern of river terraces have not been accurately defined. Due to the restriction of accuracy of DEM, there may be a discrepancy between the extracted river terraces and the actual river terraces. Therefore, the future study needs to combine the high-precision space geodesy and field geomorphic investigation to obtain the development characteristics of the river terraces in order to indicate the intermittency of neotectonics better. 


\section{Conclusion}

The Sancha river catchment's neotectonic movement is a reflection of the uplift and lateral growth of the Tibetan Plateau. The deformation of Shanpen period planation surface reflects that the crust in the study area manifests the tilt-uplift from northwest to southeast during neotectonic period, which is characterized by the resurgence of Yanshan structure. The spatial variation of Sancha river's valley shape indicates that the activity of Liuzhi-Zhijin basement fault divided the Sancha river catchment from an integrated landform unit into two relatively independent ones. The activity of Liuzhi-Zhijin basement fault has diminished gradually from northeast to southwest under the limitation of the inherited activity of the Weining-Ziyun basement fault. The spatial distribution pattern of river terrace indicates that Sancha river catchment has experienced at least four intermittent uplifts and the fault blocks at both sides of Liuzhi-Zhijin basement fault have gone through three differential uplifts.

The spatial variation of the landform type near Sancha River is characterized by periodic replacement under the background of differential uplifts of fault blocks. However, because the headward erosion of water-flow has not gone deep into, the landform development of the region, far away from the valley, is controlled by the styles of geological structure.

The spatial differentiation of the landform evolution can be divided into two cycles from the mature stage, the sub-mature stage to the young stage by Liuzhi-Zhijin basement fault. Also, the landform evolutionary stage of the northwestern fault block is younger than that of the southeastern one. However, the landform evolution of subcatchment has been also influenced by the posthumous activities of the secondary structures in the subcatchments. Therefore the spatial variation of subcatchments' landform evolution has shown the spatial variation of periodic replacement with local exceptions.

\section{Acknowledgements}

This study was sponsored by optimization research of the index value and its quantified method in the risk evaluation system of water bursting hazard in karst tunnel (Grant No. 41202213). We express our thanks to N V Chalapathi Rao and the anonymous reviewers for their constructive suggestions and comments.

\section{References}

Asode A N, Sreenivasa A and Lakkundi T K 2016 Quantitative morphometric analysis in the hard rock Hirehalla sub-basin, Bellary and Davanagere Districts, Karnataka, India using RS and GIS; Arab. J. Geosci. 9(5) 381.

Armijo R, Tapponnier P, Mercier J L and Han T 1986 Quaternary extension in southern Tibet: Field observations and tectonic implications; J. Geophys. Res. 91(B14) $13,803-13,872$.

Babault J, Bonnet S, Driessche J V D and Crave A 2007 High elevation of low-relief surfaces in mountain belts: Does it equate to post-orogenic surface uplift? Terra Nova 19(4) 272-277.

Bahrami S, Aghda S M F, Bahrami K, Rad M M and Poorhashemi S 2015 Effects of weathering and lithology on the quality of aggregates in the alluvial fans of northeast Rivand, Sabzevar, Iran; Geomorphology 241(1) 19-30.

Balen R T V, Houtgast R F and Cloetingh S A P L 2005 Neotectonics of the Netherlands: A review; Quat. Sci. Rev. 24(3-4) 439-454.

Benvenuti M, Bonini M and Moroni A 2016 Tectonic control on the Late Quaternary hydrography of the Upper Tiber Basin (Northern Apennines, Italy); Geomorphology 269 85-103.

Bishop P 2010 Long-term landscape evolution: Linking tectonics and surface processes; Earth. Surf. Proc. Land. 32(3) 329-365.

Carter A 2010 Book review: Tectonic geomorphology of mountains: A new approach to paleoseismology; Geol. Mag. 147(1) 156-157.

Cloetingh S A P L and Cornu T 2005 Surveys on environmental tectonics; Quat. Sci. Rev. 24(3-4) 235-240.

Cocco M and Rovelli A 1989 Evidence for the variation of stress drop between normal and thrust faulting earthquakes in Italy; J. Geophys. Res. 94(B7) 9399-9416.

Cui Z, Gao Q, Liu G, Pan B and Chen H 1997 The initial elevation of palaeokarst and planation surfaces on Tibet Plateau; Sci. Bull. 42(11) 934-939.

Cui Z, Li D, Feng J, Liu G and Li H 2002 The covered karst, weathering crust and karst (double-level) planation surface; Sci. China Ser. D. 45(4) 366-379.

Cyr A J, Granger D E, Olivetti V and Molin P 2014 Distinguishing between tectonic and lithologic controls on bedrock channel longitudinal profiles using cosmogenic ${ }^{10} \mathrm{Be}$ erosion rates and channel steepness index; Geomorphology 209 27-38.

Dou X, Jiang B, Qin Y, Zhenghui Q U and Xu Z 2012 Tectonic control of coalbed methane reservoirs in Panxian, Western Guizhou; Geol. J. China Univ. 18(3) 447-452 (in Chinese with English abstract).

Dufresne A, Prager C and Bösmeier A 2016 Insights into rock avalanche emplacement processes from detailed morpholithological studies of the Tschirgant deposit (Tyrol, Austria); Earth. Surf. Proc. Land. 41(5) 587-602. 
Feng Y, Zhao Z and Zhao P 2007 Basement structures and fault characteristics in Qianzhong Uplift and its circumferential areas; J. Oil Gas. Technol. 29(3) 35-38 (in Chinese with English abstract).

Finnegan N J, Hallet B, Montgomery D R, Zeitler P K, Stone J O, Anders A M and Liu Y P 2008 Coupling of rock uplift and river incision in the Namche Barwa-Gyala Peri massif, Tibet; Geol. Soc. Am. Bull. 120(1) 142-155.

Gao M 2008 Study on late cenozoic crustal tectonism; J. Geomech. D 14(4) 295-319 (in Chinese with English abstract).

Gao X 2004 The subjective and objective classification of geomorphologic forms; J. Mount. Sci. 22(3) 261-266 (in Chinese with English abstract).

Gomez C, Oguchi T and Evans I S 2016 Quantitative geomorphology with geographical information systems (GIS) for evolving societies and science; Geomorphology 260 1-3.

Gong Z 2004 Neotectonics and petroleum accumulation in offshore Chinese basins; Earth Sci. 29(5) 513-517 (in Chinese with English abstract).

Goudie A S 2016 Quantification of rock control in geomorphology; Earth. Sci. Rev. 159 374-387.

Gürbüz E, Kazancı N and Gürbüz A 2015 Strike-slip faulting, topographic growth and block movements as deduced from drainage anomalies: The Yeşilırmak river basin, northern Turkey; Geomorphology 246 634-648.

Harlin J M 1978 Statistical moments of the hypsometric curve and its density function; Math. Geol. 10(1) 59-72.

Jiang W, Han Z, Zhang J and Jiao Q 2016 Stream profile analysis, tectonic geomorphology and neotectonic activity of the Damxung-Yangbajain rift in the south Tibetan Plateau; Earth. Surf. Proc. Land. 41(10) 1312-1326.

Keller A and Pinter N 1996 Active Tectonics: Earthquakes Uplift and Landscape; Prentice Hall, Upper Saddle river, NJ.

Kong F, Yang R and Lin S 2010 Analysis of the evolution of karst environment of Weining region, Guizhou Province, West China: A proof from the sediment evolution of lake Caohai since about 73 million years; Earth. Environ. 38(2) 138-145 (in Chinese with English abstract).

Kothyari G C and B K Rastogi 2013 Tectonic control on drainage network evolution in the upper Narmada Valley: Implication to neotectonics; Geogr. J. 2013(1) 1-9.

Li D, Cui Z, Zhang Q and Ma B 2001 Development features and original altitude of a karst planation surface: Preliminary review; Sci. Bull. 46(1) 33-38.

Li D, Cui Z and Liu G 2002 A development model of red weathering crust on limestones: An example from Hunan, Guangxi, Guizhou, Yunnan and Tibet; Acta. Geogr. Sin. 57(3) 293-300.

Lifton N A and Chase C G 1992 Tectonic, climatic and lithologic influences on landscape fractal dimension and hypsometry: Implications for landscape evolution in the San Gabriel Mountains, California; Geomorphology 5(1-2) 77-114.

Lin S 1985 Plate activities and evolution of Guizhou geomorphy in Mesozoic-Cenozoic; Guizhou Geology 10(1) 8-17 (in Chinese with English abstract).

Lin S 1993 The main features of tectonic movement of Late Cenozoic era in Guizhou; Guizhou Geology 2(2) 123-130 (in Chinese with English abstract).
Liu F, Wu Z, Yang Z, Zhang Y, Wang S, Zhang H, Tong Y and Li H 2014 New progress and prospects of neotectonics and active tectonics synthetical study on eastern edge Qinghai-Xizang plateau; Geol. Bull. China 33(4) 403-418 (in Chinese with English abstract).

Liu L, Li S, Dai L, Wang Y and Liu B 2010 Structural characteristics and evolution in Guizhou Province, west of Xuefeng mountain; Chinese J. Geol. 45(1) 228-242 (in Chinese with English abstract).

Liu X, Wang S and Zhang F 2004 Fission track dating of authigenic quartz in red weathering crusts of carbonate rocks in guizhou province; Acta Geol. Sin. 78(5) 11361142.

Liu Y, Zhong J and Zhan W 1994 Basic characteristics of neotectonism in South China sea and its adjacent regions; Mar. Geol. Quat. Geol. 14(4) 1-14 (in Chinese with English abstract).

Mao J, Zhang Q and Gu S 1997 The geological characteristics and tectonic evolution of Shuicheng fault subsidence; J. Guizhou University Technol. (Nat. Sci.) 2 1-6 (in Chinese with English abstract).

Mayer L 1990 Introduction to quantitative geomorphology: An exercise manual; Prentice Hall, NJ.

Partabian A, Nourbakhsh A and Ameri S 2016 GIS-based evaluation of geomorphic response to tectonic activity in Makran Mountain Range, SE of Iran; Geos. J. 20(6) 921-934.

Pérez-Peña J V, Azor A, Azañón J M and Keller E A 2010 Active tectonics in the Sierra Nevada (Betic Cordillera, SE Spain): Insights from geomorphic indexes and drainage pattern analysis; Geomorphology 119(1-2) 74-87.

Ping H 2012 Contemporary tectonic stress field on boundaries of active tectonic blocks in and around western China; Acta. Seismol. Sin. 34(4) 439-450.

Qiu Y, Zhang Y and Ma W 1998 Tectonics and geological evolution of Xuefengintra continental orogene, South China; Geol. J. China Univ. 4(4) 432-443 (in Chinese with English abstract).

Quigley M 2017 Active tectonics and geomorphology; Prog. Phys. Geog. 34(3) 357-383.

Rana N, Singh S, Sundriyal Y P, Rawat G S and Juyal N 2016 Interpreting the geomorphometric indices for neotectonic implications: An example of Alaknanda valley, Garhwal Himalaya, India; J. Earth. Syst. Sci. 125(4) 1-14.

Ramkumar M, Menier D, Mathew M and Santosh M 2016 Geological, geophysical, and inherited tectonic imprints on the climate and contrasting coastal geomorphology of the Indian peninsula; Gondwana Res. 36 52-80.

Sarp G 2015 Tectonic controls of the North Anatolian Fault System (NAFS) on the geomorphic evolution of the alluvial fans and fan catchments in Erzincan pull-apart basin; Turkey; J. Asian. Earth. Sci. 98 116-125.

Strahler A N 1952 Hypsometric (area-altitude) analysis of erosional topography; Geol. Soc. Am. Bull. 63(11) 1117.

Sun X 2005 Research on erosion landform evolution and water and soil loss in Yishusi valley based on DEM; Bull. Soil Water Conserv. 25(4) 24-28 (in Chinese with English abstract).

Ratschbacher L, Frisch W, Chen C and Pan G 1992 Deformation and motion along the southern margin of the Lhasa block (Tibet) prior to and during the India-Asia collision; J. Geodyn. 16(1-2) 21-54. 
Wan G, Tang L, Guo T, Jin W, Hu D, Cui M and Ning F 2008 Zonation of Qianzhong (Central Guizhou) uplift and its adjacent areas; Acta. Geol. Sin. 82(3) 316-320 (in Chinese with English abstract).

Wan Y 2010 Contemporary tectonic stress field in China; Earthq. Sci. 23(4) 377-386 (in Chinese with English abstract).

Wang S, Zhang H, Wang T, Wang C, Peng C, Hu R, Chen M and Shi L 2006 Filling and evolution of the Late Paleozoic Shuicheng-Ziyun aulacogen in western Guizhou, China; Geol. Bull. China 25(3) 402-407 (in Chinese with English abstract).

Wolock D M and G J Mccabe 2015 Differences in topographic characteristics computed from 100- and 1000-m resolution digital elevation model data; Hydrol. Process. 14(6) 987-1002.

Xie F, Zhang S, Dou S, Cui X and Shu S 1999 Evolution characteristics of Quaternary tectonic stress field in the north and east margin of Qinghai-Xizang plateau; Earthq. Sci. 12(5) 550-561 (in Chinese with English abstract).

Xu J, Ji F and Zhou B 2012 On the lower chronological boundary of the Neotectonic period in China; Geosci. F. 19(5) 284-292 (in Chinese with English abstract).

$\mathrm{Xu} \mathrm{J}$ and Zhao Z 2006 Characteristics of the regional stress field and tectonic movement on the Qinghai-Tibet Plateau and in its surrounding areas; Geol. China 33(2) 283-285 (in Chinese with English abstract).

Yue G, Zhang S and Yang W 1994 Structural deformation patterns and tectonic stress field in west-central Guizhou; Chin. J. Geol. 29(1) 10-18 (in Chinese with English abstract).

Zhou D and Liu X 2005 Step-like landform and uplift of Guizhou Plateau; Earth Environ. 33(2) 79-84 (in Chinese with English abstract).

Corresponding editor: N V CHALAPTHI RAO 